\title{
Lipoma of the corpus callosum and mirror writing
}

Figure Handwriting, head CT, and MRI of the patient

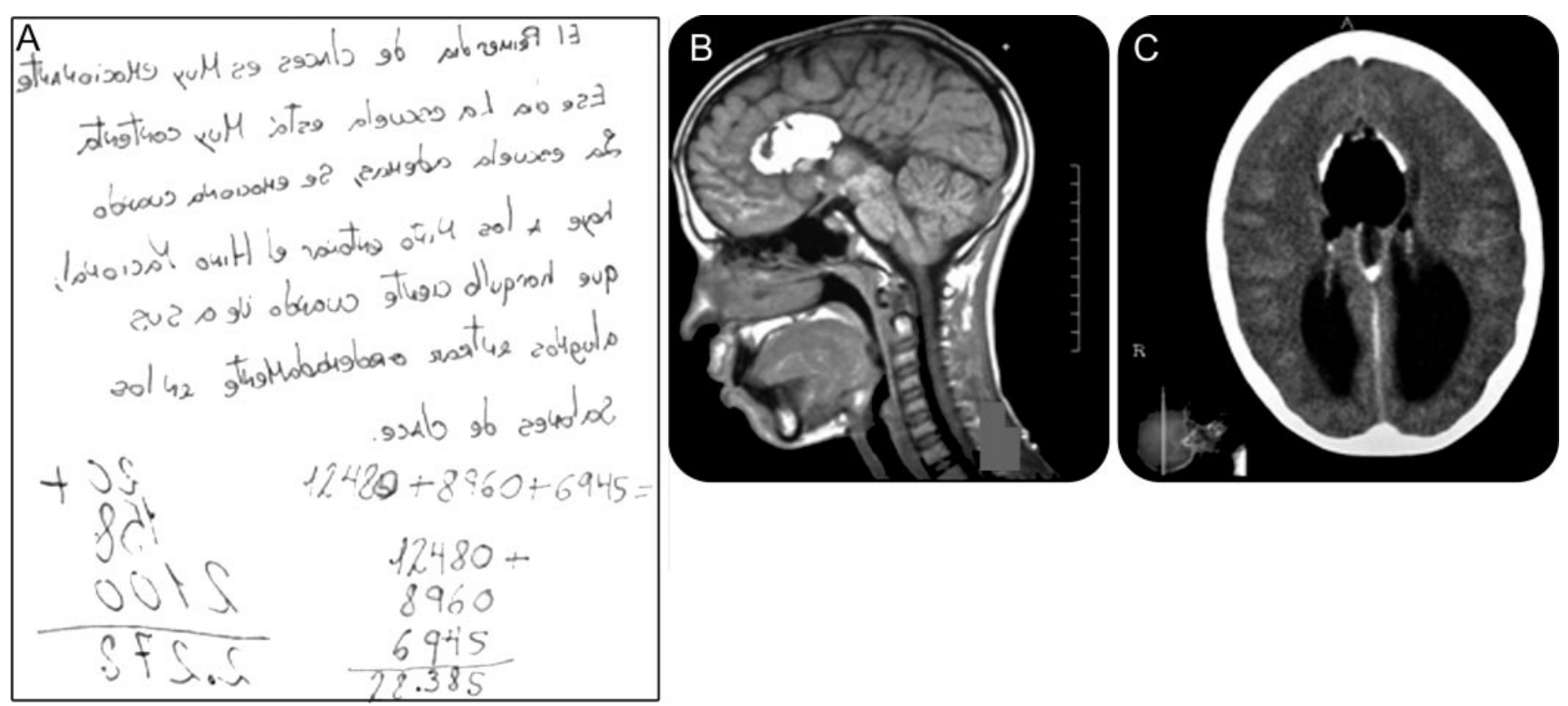

(A) The patient's writing. (B) T1, nonenhanced brain MRI shows a large hyperintense mass in the anterior corpus callosum with absence of its posterior portion. (C) Head CT shows a mass with fat attenuation and peripheral calcifications in the anterior corpus callosum. Note the symmetric dilation of the atria and occipital horns.

Mirror writing and reading are rare conditions without definitive mechanisms. ${ }^{1}$ A 19 -year-old left-handed man had a lifetime history of reading disabilities and mirror writing (figure A). The examination results were unremarkable, with fluent, nonstuttering speech. Brain imaging revealed partial agenesis of the corpus callosum (CC) with a lipoma (figures B and C). Many conditions may present with mirror writing or reading ${ }^{1,2}$; association with a lipoma and CC agenesis supports the concept that CC abnormalities may be causative. ${ }^{2} \mathrm{We}$ cannot, however, eliminate causal involvement of the supplementary motor area.

Joaquin Coromoto Hidalgo, MD, Joaquin Andrés Hidalgo, Reinier Leendertz, MD, Maracaibo, Venezuela Disclosure: The authors report no disclosures.

Address correspondence and reprint requests to Dr. Joaquín Andrés Hidalgo, Calle 72 con av. 2b, Res. San Andrés Piso 9", 4001, Maracaibo, Venezuela; Ja_hidalgo@hotmail.com

1. Schott G. Mirror writing: neurological reflections on an unusual phenomenon. J Neurol Neurosurg Psychiatry 2007;78:5-13.

2. Chan JL, Ross ED. Left-handed mirror writing following right anterior cerebral artery infarction: evidence for nonmirror transformation of motor programs by right supplementary motor area. Neurology 1988;38:59-63. 


\title{
Neurology
}

\author{
Lipoma of the corpus callosum and mirror writing \\ Joaquín Coromoto Hidalgo, Joaquín Andrés Hidalgo and Reinier Leendertz \\ Neurology 2010;75;936 \\ DOI 10.1212/WNL.0b013e3181f11e23
}

This information is current as of September 6, 2010

\section{Updated Information \&} Services

References

Subspecialty Collections

Permissions \& Licensing

Reprints including high resolution figures, can be found at: http://n.neurology.org/content/75/10/936.full

This article cites 2 articles, 2 of which you can access for free at: http://n.neurology.org/content/75/10/936.full\#ref-list-1

This article, along with others on similar topics, appears in the following collection(s):

All Neuropsychology/Behavior

http://n.neurology.org/cgi/collection/all_neuropsychology_behavior Developmental disorders

http://n.neurology.org/cgi/collection/developmental_disorders MRI

http://n.neurology.org/cgi/collection/mri

Information about reproducing this article in parts (figures,tables) or in its entirety can be found online at:

http://www.neurology.org/about/about_the_journal\#permissions

Information about ordering reprints can be found online:

http://n.neurology.org/subscribers/advertise

Neurology ${ }^{\circledR}$ is the official journal of the American Academy of Neurology. Published continuously since 1951, it is now a weekly with 48 issues per year. Copyright . All rights reserved. Print ISSN: 0028-3878. Online ISSN: 1526-632X.

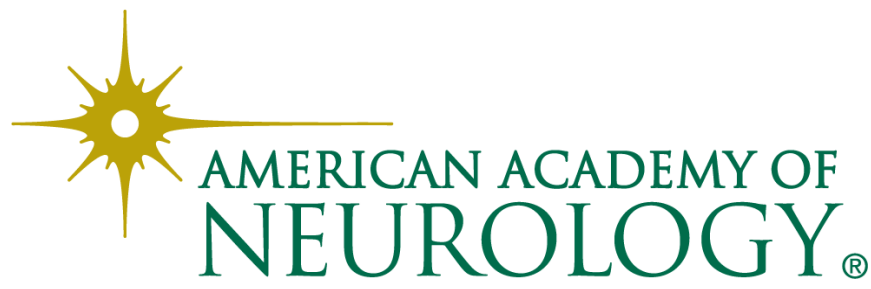

